\title{
Değerler, Gençlik ve Sivil Toplum Kuruluşları
}

\author{
Levent ERASLAN*
}

\author{
Erdi ERDOĞAN **
}

Öz

Değer eğitimi, son yıllarda önemli çalışma alanlarından biri haline gelmiştir. Sağlıklı bir toplum düzeninin sağlanması açısından önemini gelecek yıllarda da koruyacağı öngörülmektedir. Bu araştırma değerler eğitimi bağlamında üniversite gençlerinin hem değer kavramına bakışlarını hem de sivil toplum kuruluşları - değer ilişkisine dönük görüşlerini belirlemek amacıyla yapılmıştır. Araştırma, hem nicel hem de nitel olarak modellenmiştir. Çalışma, nicel açıdan tarama modeline dayalı betimseldir. Nitel açıdan ise kişilere evrensel ve yerel değer algıları sorulmuştur. Nicel verilerinin analizinde SPSS 15. 0 paket programından yararlanılmış, yüzde ve frekans değerleri belirtilmiştir. Nitel verilerin analizinde ise içerik analizinden yararlanılmıştır. Araştırmanın çalışma grubunu 1828 yaş arasındaki 170 kişiden oluşan üniversite öğrencileri ve üniversite mezunları oluşturmaktadır. Üniversite öğrencilerinden oluşan çalışma grubu; PDR, Türkçe Öğretmenliği, Sınıf öğretmenliği, BÖTE, Mezun grup ise; İşletme, İktisat, Ekonometri, Kamu Yönetimi, Edebiyat, Tarih, Coğrafya, Müzik, Din Kültürü ve Matematik gibi alanlardan oluşmaktadır. Araştırmanın bulguları ışığında, katılımcıların sivil toplum kuruluşlarının değer eğitimi sürecinde önemli bir yerinin olduğu, yerel değerler olarak aile, din ve hoşgörüyü, evrensel değerler olarak barış, insan hakları ve özgürlüğü gördükleri, değerlerine oldukça önem verdikleri ve aile değerine özel bir anlam yükledikleri sonuçlarına ulaşılmıştır.

Anahtar Kelimeler: Değer, Değer Eğitimi, Değer Analizi, Sivil Toplum.

\section{Values, Youth and Non-Govermental Organizations}

\begin{abstract}
In the recent years, value education has become one of the important study fields. It is foreseen that it will maintain its importance for providing healty society order in the coming years. This research aims to specify university students' perpectives devoted to both value concepts and non govermental organizations - value relations within the context of values education. The research was designed with both quantitative and qualitative method. The study is descriptive in terms of quantitative method. In terms of qualitative method, universal and local value perceptions were asked to participants. In the analysis of quantitative datas, SPSS 15.0 package software was used, percentage and frequency values were indicated. Furthermore, in the analysis of qualitative datas, content analysis method was used. Research's study group comprises of 170 university students and graduate students in the age of between $18-28$. Study group of university students involve in psychological counseling and guidance, Turkish education, primary school teacher training, computer and instructional technologies, graduate students group comprises of management, economy, econo-
\end{abstract}

\footnotetext{
* Doç. Dr, Kırıkkale Üniversitesi, Eğitim Yönetimi, Denetimi, Teftişi, Planlaması ve Ekonomisi Bölümü, leraslan@yahoo.com

** Arş. Gör., Kırıkkale Üniversitesi, Sosyal Bilgiler Eğitimi Bölümü, erdierdogan@kku.edu.tr
} 
metrics, public administration, literature, history, geography, music, religious culture and mathematics. In the light of research's findings, it was reached to results that participants attach importance to non-govermental organizations in the process of value education, while participants care family, religion and tolerance as local values, they think peace, human rights and freedom as universal values and participants give particular importance to family value.

Keywords: Value, Value Education, Value Analysis, Civil Society.

\section{GİIŞ}

Dünyamız insanoğlunun şiddetli ve acımasız mücadelelerine sahne olmuştur. Bu mücadeleler esnasında bireyler insani yönlerini unutmuş, farklı psikolojik süreçlerin de etkisiyle yıkıcı davranışlarda bulunmuşlardır. Düşünebilen canlıların bu davranışları halen tarihte utanç dönemleri olarak belirmektedir. Bu bağlamda barış; yeryüzünde ulaşılması en kolay, fakat insan zihni tarafından öneminin kavranması noktasında en zor olan kavramlardan biridir. Topluluklar çeşitli sebeplerden dolayı barışı dönemsel farklılıklarla zedelemişlerdir. 21. yüzyıl, insanoğlunun geçmişinin farkına varıp, dünyayı evrensel barış kültürüyle yönettiği bir dönem olmalıdır. Bu döneme ulaşabilmemiz için de bireyler tarafından kabul edilmesi gereken evrensel değerler bulunmaktadır.

Değer kavramının şu ana kadar farklı disiplinler tarafından farklı boyutlarına vurgu yapılan birçok tanımı mevcuttur. Farklılaşan tanımlamalar olsa da Türk Dil Kurumu (TDK) (2014) değeri şöyle tanımlamıştır; "bir şeyin önemini belirlemeye yarayan soyut ölçü, bir şeyin değdiği karşılık, kıymet". Macionis'e (2012, 66) göre ise değerler; insanların cazip, güzel ve iyi olanın ne olduğuna karar verirken kullandıkları, kültürel olarak belirlenmiş standartları ve genel biçimde sosyal yaşamın ana hatları oluşturma olarak tanımlanmıştır. Değerler, bir şeyin doğru ya da yanlış olduğunu konusundaki inançlar, yargılardır (Dilmaç ve diğ., 2009; 10). Bolay (2007) değeri, "insanların değer verdiği ve ulaşmak için peşinden koştuğu, elde etmeyi şiddetle arzu ettiği şeyler" olarak tanımlamıştır. Doğan $(2011 ; 327)$ ise değer kavramı- nı şöyle tanımlamıştır; "Değer kavramı bir kişi ya da bir topluluğun ideal kabul ettiği var olma ya da hareket etme tarzıdır". Tüm bu tanımlardan hareketle genel bir tanımlama gerekirse değer; kişilerin toplum içinde davranışlarını düzenleyen, bireysel istekler yerine bütünün isteklerini ön plana çıkaran, toplumu devlet yaptırımı dışındaki etkilere göre şekillendiren davranış özellikleri olarak tanımlayabiliriz. Değerin tanımının farklılığı yanında diğer önemli bir nokta da değerleri kazandırmada hangi çevrelerin ve kurumların görev üstleneceğidir. Bu hususta en temel eğitim kurumları olan okullar etkililiğini hissettirmektedir.

Değerler bir döngüden ibarettir. Modern devletlerde değerler, köklerini hümanizme dayalı gelenek ve göreneklerden alırlar. Daha sonra devlet ve devlet kurumları tarafından yasal bir zemine oturtularak formal eğitim kurumlarında kazandırılması hedeflenir. $\mathrm{Bu}$ değerlere uygun olarak eğitim yapılır. Bu eğitimi almış bireylerin bir araya gelmesiyle toplumun kültürü oluşur. Daha sonra oluşan bu kültür gelenek ve görenekleri şekillendirerek değerlerin günümüz ihtiyaçlarına uygun bir şekle bürünmesine yol açar. Toplum düzeninin ve ihtiyaçların değişimi bağlamında, mevcut sistemin yeni işlevleri, üretim biçimi, politika değişimi, düşünsel yapı ve hayat tarzı değişimi nedenleriyle değerlerin farklılaştığını belirtilmiştir (Memiş ve Gedik, 2010; 124),.

Ailede ve yakın çevrede başlayan değer aktarımı, bir formal eğitim kurumu olan okulda yapılmaya başlanınca daha sistematik bir hal alır. Okul, var olan değerlerin korunması ve sürdürülmesine katkısının yanında değişen 
toplumsal düzenin değer oluşturma süreçlerine de katkı sunmaktadır (Doğan, 2011; 199). Değerlerin öğrencilere benimsetilmesinde okullar önemli görevleri bulunan, değer aktarımının sağlanacağı resmi kurumlardır (Yel ve Aladağ, 2012; 125). Verilmek istenilen değerler, üniteler, konular, okuma parçaları gibi eğitim materyalleri içine gizlenebilir.

Okullar toplumsal dönüşümü sağlayan en temel kurumlardan biridir. Bu bağlamda değerlerin bireylere aktarılmasında da önemli roller üstlenmektedir. Okullarda birçok ders ve ara disiplin kapsamında öğrencilere değerlerin aktarılması amaçlanmaktadır. Özellikle sosyal bilgiler dersi kapsamında sorumluluk, barış, vatanseverlik, hoşgörü, farklılıklara saygı, dürüstlük, adil olma vb. gibi değerlerin bireylere aktarılması hedeflenmektedir (MEB, 2005). Fakat bu noktada dikkat edilmesi gereken durum, okulun eğitim-öğretim hedefleri ve öğrencilerin hedefleri ve değerleri arasındaki tutarlılığın sağlanmasıdır. Bu durum hakkında Yılmaz $(2009 ; 111)$ tutarlılık düzeyinin hedeflere ulaşma düzeyini etkilediğini belirtmiştir.

Değerlerin toplumun geleceğini şekillendirmede önemli rol oynadığını göz önüne aldığımızda, değer eğitimi sürecini etkili şekilde geçirmiş bireylerden oluşan bir toplum, olası sorunların önlenmesi ve var olan sorunların çözümünde barışçı yolları kullanarak birliğini devam ettirecektir. Eğitimin kendisi bir değer olmasından dolayı, bireyi de sahip olduğu değerler aracılığıyla şekillendirecektir (Neachu, 2013; 106). Mustafa Kemal Atatürk'ün "Yurtta sulh, cihanda sulh" söylemi, ülke içinde gerekli ortam sağlandıktan sonra gerçekleşecektir. Ulusal düzeyde etkili bir değer aktarım süreci dünya barışına da katkı sağlayacaktır.

Devlet olanakları her alanda bireylerin ihtiyaçlarını karşılamaya yeterli gelmemektedir. $\mathrm{Bu}$ noktada sivil toplum kuruluşları yükselen bir etki unsuru olarak ortaya çıkmaktadır. Bu bağ- lamda değer eğitimi sürecinde de etkili organizasyonlardan biri sivil toplum kuruluşları olarak belirmektedir. Değerlerin aktarılmasında, korunmasında ve yeniden üretimi ile ilgili analizlerde görülen STK'lar, dünya genelinde değer üretiminde önemli bir role sahiptir (Hildy, 2004). STK'ların temel felsefesi toplumun ihtiyaç ve değerlerinin temsilcisi olmaktır. STK'lar bu misyonu ile toplumsal değerler üzerine kurulur ve aynı zamanda değerler de STK'lar üzerinden aktarılır ya da değiştirilir. Bir başka deyişle "Her STK Bir Değer Üstüne Kurulmuştur". Sivil toplum kuruluşları değerler eğitimi sürecine farklı açılardan katkı yapabilmektedir. Bu konu hakkında Eraslan ve diğ. (2015; 92-97) uzmanlık desteği olarak eğitim programı hazırlama, eğitim materyali hazırlama, öğretmen eğitimi ve politika geliştirme; dinamik organizasyonel destek bakımından değer tanıtımı, izleme-değerlendirme-kontrol, alternatif üretebilme kapasitesi, savunuculuk pratiği; ortaklık desteği olarak ise değerlerin eğitimine yönelik okul-STK işbirliği, STK olanaklarının paylaşımı, yazılı ve görsel medya desteği, proje hazırlama ve uygulama desteği, ekonomik destek sağlama kapasitesi konusunda değer eğitimi sürecine sivil toplum kuruluşlarının destek olabileceğini belirtmişlerdir.

Sivil toplum kuruluşlarının yukarıda belirtilen değer eğitimi sürecindeki işlevlerini göz önüne aldığımızda, dünya düzeninin ve toplumsal yapının ortaya çıkardığı yeni değer anlayışlarını mevcut düzenle uyumluluğunu sağlayacak temel organizasyonlardan biri olduğu açıkça görülmektedir. Şekillendirici etkisiyle hümanizme yönelimi sağlayacak olan bu kuruluşlar, sivil bireylerin sesini devlet kademelerinde de duyurmasıyla, halkın beklentilerini karşılama olanağı sunacaktır. Bu bağlamda bu çalışmada da öğrencilerin değerlere yönelik görüşlerinin betimlenmek istenmesinin yanında özellikle sivil toplum kuruluşları-değer eğitimi süreci etkileşimi üniversite öğrencilerinin ve mezun- 
larının gözünden ortaya konulmak istenmiştir. Literatürde öğretmenlerin ve öğrencilerin değerlere yönelik görüşleri farklı çalışmalarda ortaya konulmasına rağmen, sivil toplum ve değer eğitimi süreci etkileşimi yeterince açılığa kavuşturulmamıştır. Bu çalışmada hem katılımcıların değerlere ilişkin görüşlerine yer verilmesiyle, hem de STK-değer ilişkisini katılımcıların yanitları neticesinde ortaya konulmasının amaçlanmasıyla alandaki eksikliğin giderileceği düşünülmektedir.

\section{YÖNTEM}

\section{1 Çalışma Grubu}

Araştırmanın çalışma grubunu 18-28 yaş grubunda üniversite öğrencileri ve üniversite mezunları oluşturmaktadır. Üniversite öğrencilerinden oluşan çalışma grubu; PDR, Türkçe Öğretmenliği, Sınıf öğretmenliği, BÖTE bölümlerinde öğrenimlerine devam etmektedirler. Üniversite mezunu öğrenciler ise; İşletme, İktisat, Ekonometri, Kamu Yönetimi, Edebiyat, Tarih, Coğrafya, Müzik, Din Kültürü ve Matematik bölümleri mezunudur. Araştırmaya Kırıkkale Üniversitesinde 2013-2014 eğitim öğretim döneminde öğrenim gören lisans öğrencileri ve pedagojik formasyon eğitimi alan mezun grup öğrencileri katılmıştır. Çalışma grubunun seçiminde seçkisiz örnekleme yöntemlerinden basit seçkisiz örnekleme yönteminden yararlanılmıştır. Seçkisiz örneklemede tüm birimler örnekleme seçilmek için diğer birimlerin etkisinden bağımsız olarak eşit şansa sahiptir (Büyüköztürk, 2013; 85). Seçkisiz örneklemeye hizmet edebilmek için öncelikle evrendeki tüm kişilerin bilgileri listede toplanmış, ardından kura yoluyla rastgele seçim yapılmış, örneklemeye 170 kişi dâhil edilmiştir.

\subsection{Araştırmanın Modeli}

Bu araştırmada hem nicel hem de nitel yöntemlerden yararlanılmıştır. Araştırmanın nicel boyutu, tarama modeline dayalı (survey) betimsel bir çalışma niteliğindedir. Tarama araştırmaları, bir grubun belirli özelliklerini belirlemek için verilerin toplanmasını amaçlayan çalışmalar olarak adlandırılmaktadır (Büyüköztürk ve diğ., 2013; 14). Bu yöntem yoluyla üniversite öğrencilerinin değerlere ve STK-değer ilişkisine dönük algıları belirlenmeye çalışılmıştır. Araştırmanın ikinci kısmı ise nitel araştırma şeklinde tasarlanmıştır. Nitel araştırmalar; gözlem, görüşme ve doküman analizi gibi nitel veri toplama yöntemlerinin kullanıldığı, algıların ve olayların doğal ortamda gerçekçi ve bütüncül bir biçimde ortaya konmasına yönelik nitel bir sürecin izlendiği araştırmalardır (Yıldırım ve Şimşek, 2013; 45).

\subsection{Veri Toplama Aracı}

Tarama çalışmasında değerler ve STK-değer ilişkisini ortaya koymak amacıyla araştırmacılar tarafından 12 maddeden oluşan "Değerler ve STK-Değerler İlişkisi Algı Anketi" geliştirilmiştir. Anket maddeleri literatür taramasının ardından hazırlanmıştır. Anket maddeleri tamamen katılıyorum ... katılmıyorum... şeklinde cevap kategorilerine sahip 5'li Likert tipindedir. İlk etapta 15 maddeden oluşan veri toplama aracı, ilgili alana yönelik çalışmaları bulunan üç uzman tarafından incelenmiş, geri bildirimler neticesinde toplam madde sayısı 12'ye düşürülmüştür. Buna ek olarak katılımc1lara 8 değer verilmiş (Demokrasi, Din, Hoşgörü, Doğa, Aile, Barış, Özgürlük, İnsan hakları) ve önem sırasına koymaları istenmiştir. Araştırmanın nitel kısmında ise katılımcıların evrensel ve yerel değer tercihlerini belirlemek amacıyla 2 tane açı uçlu soru sorulmuştur. Anket formunun uzman görüşleri neticesinde 
şekilsel ve dil yönünden düzeltmeleri yapılmıştır. Ardından pilot uygulama gerçekleştirilmiştir. Pilot uygulama verilerinin analizi sonucunda anket formunun Cronbach Alfa güvenirlik değeri 0,82 bulunmuş ve sonuç itibari ile anket formu asıl uygulama için son haline kavuşturulmuştur.

\subsection{Verilerin Analizi}

Araştırma verileri, 18-28 yaş aralığında olan 170 üniversite öğrencisinden ve üniversite mezunundan toplanmıştır. Katılımcıların anket maddelerine verdikleri cevaplar SPSS 15 . 0 paket programı kullanılarak analiz edilmiş, frekans ve yüzdeleri hesaplanmıştır. Buna ek olarak öğrencilerin değer sıralama tercihleri de frekans ve yüzde olarak betimlenmiştir. Anket formunun son bölümünde yer alan açık uçlu sorular içerik analiziyle çözümlenmiştir. İçerik analizinde amaç toplanan veriler ışığında ele alınan verileri kodlamak, birbirine benzeyen kodları aynı tema altında toplamak ve anlaşılır bir şekilde sunmaktır (Aktaş, 2014; 347-348). Araştırma bağlamında elde edilen veriler 3 araştırmacı tarafından kodlanmış, uzlaşıya varıldıktan sonra analize son hali verilmiştir. Verilen cevaplar ışı̆̆ında yüzde ve frekans hesaplamalarıyla birlikte katılımcıların yerel ve evrensel değer algıları sunulmuştur.

\section{BULGULAR ve YORUMLAR}

\section{1 Önerme Grubu}

Tablo 1. Değerlerim için yaşarım

\begin{tabular}{lcc}
\hline \multicolumn{1}{c}{ 1.Önerme } & Frekans & Yüzde (\%) \\
\hline Hiç Katılmiyorum & 2 & 1,2 \\
Çok az katıliyorum & 5 & 2,9 \\
Katıliyorum & 13 & 7,6 \\
Büyük Ölçüde Katılıyorum & 90 & 52,3 \\
Tamamen Katıliyorum & 60 & 34,9 \\
Toplam & 170 & 100 \\
\hline
\end{tabular}

Çalışma grubunun çok büyük bir oranı bu önermeye katıldıklarını belirtmişlerdir. Grubun \% 94.8'i değerleri için yaşadıklarını belirtmiştir. Bu tabloya göre değerlerin üniversite öğrencileri ve üniversite mezunu gençler için çok önemli olduğu görülmektedir. Aslında bu sonuç Türk halkının genelinde rastlanabilir. Ayrıca bu sonuca göre "değer bizatihi kendisi bir değerdir" sonucuna da ulaşılabilir.

Tablo 2. Değerlerim değişebilir

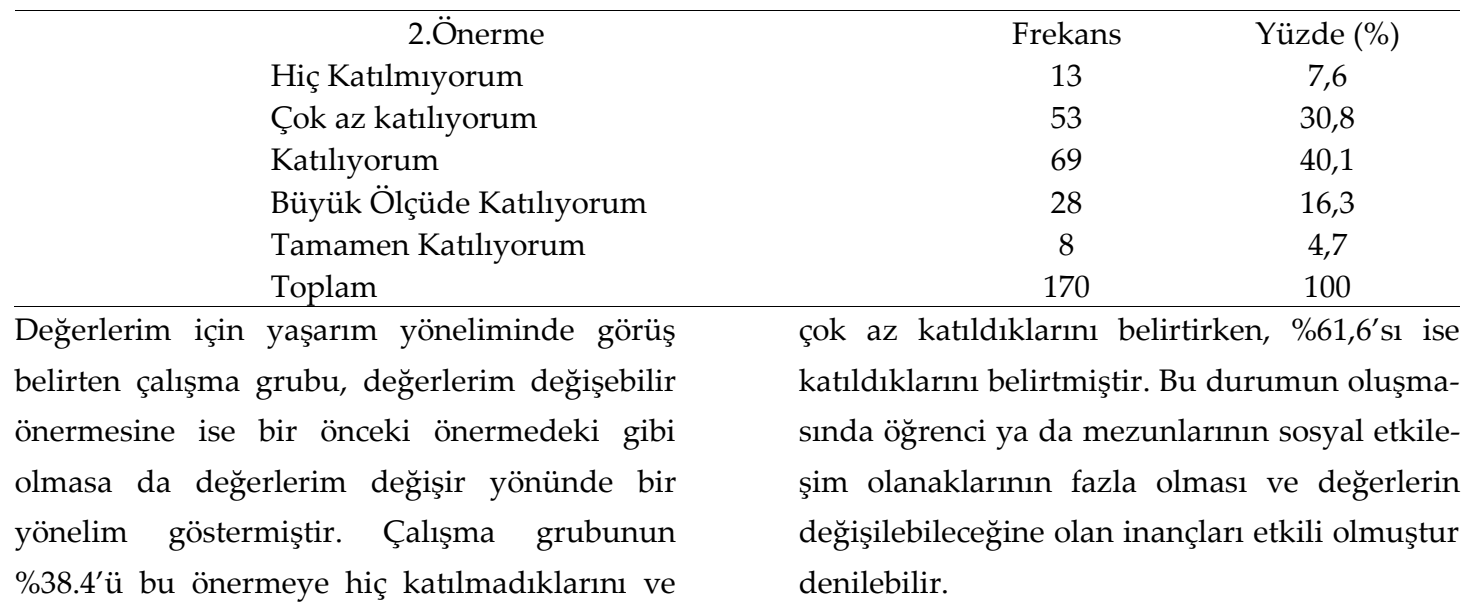


Tablo 3. Anne ve babamın değerleri ile benim değerlerim farklıdır

\begin{tabular}{ccc}
\hline \multicolumn{1}{c}{ 3.Önerme } & \multicolumn{1}{c}{ Frekans } & Yüzde (\%) \\
\hline Hiç Katılmıyorum & 13 & 7,6 \\
Çok az katılıyorum & 46 & 26,7 \\
Katılıyorum & 69 & 40,1 \\
Büyük Ölçüde Katılıyorum & 27 & 15,7 \\
Tamamen Katılıyorum & 16 & 100 \\
Toplam & bamın değerleri ile benim değerlerim farklıdır \\
\hline $\begin{array}{l}\text { Yukarıdaki sonucu destekleyen bir yönelim bu } \\
\text { önermede görülmüştür. Çalışma grubunun }\end{array}$ & önermesine katılıyorum-tamamen katılıyorum \\
\%34.3'ü bu önermeye hiç katılmadıklarını ve & doğrultusunda yönelim göstermişlerdir. Bu \\
çok az katıldıklarını belirtmişlerdir. Bu sonuç & verilere göre üniversite öğrencileri ve üniversi- \\
büyük bir olasılıkla bir önceki önermede değer- & te mezunu gençlerde aile değerlerinin yanında \\
lerim değişmez yöneliminde olan grubun vur- & kendi farklı değerler sistematiklerinin olduğu \\
gulamasıdır. Grubun \%65.7'si ise anne ve ba- & söylenebilir.
\end{tabular}

Tablo 4. Değerlerin okulda öğretilebileceğine inanmıyorum

\begin{tabular}{lcc}
\hline \multicolumn{1}{c}{ 4.Önerme } & Frekans & Yüzde (\%) \\
\hline Hiç Katılmiyorum & 27 & 15,7 \\
Çok az katıliyorum & 38 & 22,1 \\
Katıliyorum & 54 & 31,4 \\
Büyük Ölçüde Katılıyorum & 33 & 19,2 \\
Tamamen Katıliyorum & 14 & 8,1 \\
Toplam & 170 & 100 \\
\hline
\end{tabular}

Değerlerin nerede öğretileceği temel bir tartışma sorusudur. Buna göre çalışma grubunun \% 37.8'i okullarda öğretim yoluyla öğretmen ve programlar yoluyla değerlerin okulda öğretilebileceğine hiç katılmadıklarını ve çok az katıl- dıklarını belirtmişlerdir. Çalışma grubunun \%62.2'si ise olumlu bir yönelim göstermiştir. Okulların mevcut ile değer öğretiminde çok da yeterli olmadıkları ama yine de önemli bir unsur olduğu sonucuna ulaşılabilir.

Tablo 5. Sivil toplum kuruluşlarının değer eğitiminde etkili olduğunu düşünüyorum

\begin{tabular}{lcc}
\multicolumn{1}{c}{ 5.Önerme } & Frekans & Yüzde (\%) \\
\hline Hiç Katılmiyorum & 18 & 10,5 \\
Çok az katıliyorum & 35 & 20,3 \\
Katıliyorum & 64 & 37,2 \\
Büyük Ölçüde Katılıyorum & 43 & 25,0 \\
Tamamen Katılıyorum & 11 & 6,4 \\
Toplam & 170 & 100 \\
\hline
\end{tabular}

Değer öğretimi için devlet ve toplumun dişında üçüncü bir unsur olarak STK'ların etki alanı sorulduğunda çalışma grubunun \%30.8'i bu önermeye hiç katılmadıklarını ve çok az katıldıklarını belirtmişlerdir. Çalışma grubunun \%69.2'si ise bu önermeye olumlu bakmışlardır. Okulun değer eğitimine dönük olumlu bakış bu önermede 7 puanlık bir artış STK'lar lehindedir. Bu sonuca göre STK'ların değer eğitiminde önemli bir aktör olarak görülmektedir. 
Tablo 6. Aslında sivil toplum özü itibariyle bir değerdir

\begin{tabular}{lcc}
\hline \multicolumn{1}{c}{ 6.Önerme } & Frekans & Yüzde (\%) \\
\hline Hiç Katılmiyorum & 13 & 7,6 \\
Çok az katılıyorum & 32 & 18,6 \\
Katıliyorum & 53 & 30,8 \\
Büyük Ölçüde Katılıyorum & 59 & 34,3 \\
Tamamen Katıllyorum & 14 & 8,1 \\
Toplam & 170 & 100 \\
\hline
\end{tabular}

Sivil toplumun temelde bir değer olduğu ve sivil düşüncenin önemli bir zemini olduğuna çalışma grubunun \%7.6'sı dişında kalan \%92.4'lük bir kesim Çok az katıliyorumTamamen Katılıyorum skalasında yönelim göstermiştir. Bu durum oldukça önemlidir.

Tablo 7. Değer öğretiminde STK'lar ile MEB işbirliğinin bir anlamı yoktur

\begin{tabular}{lcc}
\hline \multicolumn{1}{c}{ 7.Önerme } & Frekans & Yüzde (\%) \\
\hline Hiç Katılmiyorum & 60 & 34,9 \\
Çok az katıliyorum & 46 & 26,7 \\
Katıliyorum & 45 & 26,2 \\
Büyük Ölçüde Katılıyorum & 12 & 7,0 \\
Tamamen Katıliyorum & 5 & 2,9 \\
Toplam & 170 & 100
\end{tabular}

Olumsuz kök ifadesiyle sorulan bu çapraz soruda çalışma grubunun \%9.9'u değer öğretiminde STK'lar ile MEB işbirliğine hiç katılmadıklarını ve çok az katıldıklarını belirtmişlerken, \%90.1'i ise olumlu bir şekilde bu işbirliği-
Üniversite öğrencileri ve üniversite mezunu gençlerde sivil toplumcu bir bilincin değer olarak yer alması ülkenin demokratikleşmesi ve sivil bir anlayışın temele alınmasında önem arz etmektedir.

Tablo 8. STK'lar toplumda yeni değerler üretebilir

\begin{tabular}{lcc}
\hline \multicolumn{1}{c}{ 8.Önerme } & Frekans & Yüzde (\%) \\
\hline Hiç Katılmiyorum & 12 & 7,0 \\
Çok az katıliyorum & 29 & 16,9 \\
Katılıyorum & 66 & 38,4 \\
Büyük Ölçüde Katılıyorum & 49 & 28,5 \\
Tamamen Katıliyorum & 11 & 6,4 \\
Toplam & 170 & 100 \\
\hline
\end{tabular}

STK'ların toplumsal yaşamda yeni üretebilme kapasitelerinin sorgulandı $\breve{g}_{1}$ bu önermeye çalışma grubunun \%7'si hiç katılmadıklarını ifade etmektedir. Çok az katılıyorum-Tamamen nin olması gerekliliği üzerinde durmaktadır. $\mathrm{Bu}$ önermeden hem MEB hem STK'lar önemli sonuçlar çıkartarak ortaklık ve işbirliği kapasitelerini değerlendirmelidirler.

Tablo 9. Öğretmenler değer öğretiminde önemli unsurlardır

\begin{tabular}{lcc}
\hline 9.Önerme & Frekans & Yüzde (\%) \\
\hline Hiç Katılmiyorum & 2 & 1,2 \\
Çok az katıliyorum & 3 & 1,7 \\
Katıliyorum & 18 & 10,5
\end{tabular}


Büyük Ölçüde Katılıyorum

Tamamen Katıliyorum

Toplam

Çalışma grubu öğretmenlerin önemli bir unsur olarak değer öğretimdeki kritik yönüne dönük bir yönelim göstermişlerdir. Buna göre çalışma grubunun \%3.9'u bu önermeye hiç ya da çok az katıldıklarını belirtirken geri kalan \%96.1'i katıldıklarını belirtmişlerdir. Öğretmenlerin

Tablo 10. Öğretim kademelerine Değerler Eğitimi adlı bir ders konulmalıdır

\begin{tabular}{lcc}
\hline \multicolumn{1}{c}{ 10.Önerme } & Frekans & Yüzde (\%) \\
\hline Hiç Katılmiyorum & 4 & 2,3 \\
Çok az katıliyorum & 14 & 8,1 \\
Katılıyorum & 55 & 32,0 \\
Büyük Ölçüde Katılıyorum & 65 & 37,8 \\
Tamamen Katıliyorum & 32 & 18,6 \\
Toplam & 170 & 100 \\
\hline
\end{tabular}

Çalışma grubunun yüksek olumlu yönelim gösterdiği (\%89.6) bu önerme sonucuna göre "Değerler Eğitimi" adlı müstakil bir dersin programlara aktarılması istenmektedir. Çeşitli dersler ya da projeler ile okullarda öğretilmek

Tablo 11. Değerlerin günümüzde çok kolay aşındığını düşünüyorum

\begin{tabular}{lcc}
\multicolumn{1}{c}{ 11.Önerme } & Frekans & Yüzde (\%) \\
\hline Hiç Katılmiyorum & 5 & 2,9 \\
Çok az katıliyorum & 14 & 8,1 \\
Katıliyorum & 27 & 15,7 \\
Büyük Ölçüde Katılıyorum & 67 & 39,0 \\
Tamamen Katıliyorum & 57 & 33,1 \\
Toplam & 170 & 100 \\
\hline
\end{tabular}

Genel değer analizine yönelik olarak yöneltilen bu önermeye göre çalışma grubunun büyük bir çoğunluğu değerlerin kolaylıkla aşındığına dönük kaygılarını belirtmiştir. Değerlerim için yaşarım önermesine büyük bir oranda olumlu istenen değerlerin bir bütün olarak ele alınması gerekliliği görülmektedir. Talim ve Terbiye Kurulunun dikkate alması gereken bir sonuçtur.

Tablo 12. Yazılı ve görsel medya değerleri bozmaktadır.

\begin{tabular}{lcc}
\hline \multicolumn{1}{c}{ 12.Önerme } & Frekans & Yüzde (\%) \\
\hline Hiç Katılmiyorum & 4 & 2,3 \\
Çok az katılıyorum & 9 & 5,2 \\
Katılıyorum & 29 & 16,9 \\
Büyük Ölçüde Katılıyorum & 65 & 37,8 \\
Tamamen Katılıyorum & 64 & 37,2 \\
Toplam & 170 & 100 \\
\hline
\end{tabular}

Genel değer analizine yönelik olarak ikinci soruda değer bozulmasında yazılı ve görsel medyanın rolü çalışma grubuna yöneltilmiştir. bakan çalışma grubunun \%89'ü değer aşınması tehlikesine işaret etmektedir. \%11'lik bir kesim ise bu önermeye hiç-çok az katıldıklarını belirtmişlerdir. Buna göre medyanın değerlerin bozulmasında önemli bir unsur olduğunu belirtenlerin oranı \%92,5'tir. Hiç-çok az katılıyorum yönelimi ise 
\%7,5'tür. Buna göre üniversite öğrencileri ve üniversite mezunu gençler medyayı değerlerin aşınması ve bozulmasında önemli bir unsur olarak görmektedirler sonucu çıkmaktadır.

\subsection{Değerler}

Örneklem grubuna değerleri sizin için en önemli olandan (1) en az önemli olana (8) sıralayınız yönergesi sunulmuş buna göre aşağıdaki değerler çalışma grubu tarafından sıralanmıştır.
1) Demokrasi
2) Din
3) Hoşgörü
4) Doğa
5) Aile
6) Barış
7) Özgürlük
8) İnsan hakları

\subsubsection{Demokrasi Değeri}

Tablo 13. Demokrasi Değeri

\begin{tabular}{ccc}
\hline Öncelikler & Frekans & Yüzde (\%) \\
\hline 1 & 5 & 2,9 \\
2 & 10 & 5,8 \\
3 & 25 & 14,5 \\
4 & 32 & 18,6 \\
5 & 35 & 20,3 \\
6 & 28 & 16,3 \\
7 & 23 & 13,4 \\
8 & 13 & 7,6 \\
Toplam & 170 & 100 \\
\hline
\end{tabular}

Çalışma grubunda demokrasi değerini birinci önceliği yazan 5 kişidir. İkinci önceliğe yazan 10 , 3. önceliğe yazanlar ise 25 kişidir. Genelde orta düzey tercih alanı olan 4,5,6, öncelikte demokrasi değeri yer bulmuştur. 5. Öncelik 35 kişi ile \%20.3’lük bir yüzde ile en yüksek noktadır. Demokrasi değerini son sıraya koyan 13 kişidir (\%7.6) .

\subsubsection{Din Değeri}

Tablo 14. Din Değeri

\begin{tabular}{ccc}
\hline Öncelikler & Frekans & Yüzde (\%) \\
\hline 1 & 34 & 19,8 \\
2 & 25 & 14,5 \\
3 & 19 & 11,0 \\
4 & 12 & 7,0 \\
5 & 4 & 2,3 \\
6 & 20 & 11,6 \\
7 & 16 & 9,3 \\
8 & 41 & 23,8 \\
Toplam & 170 & 100 \\
\hline
\end{tabular}

Çalışma grubuna dini değerleriniz öncelik sırasında nerededir? İfadesine 1.,2., 3. Öncelik yanıtını verenler grubun $\% 45.3^{\prime}$ dür. Orta sıralarda dini değerleri yazan $(4 ., 5 ., 6$.) 36 kişidir. Aynı şekilde dini değerleri sıralamanın sekizinci skalasına yerleştirenlerin sayısı 41 'dir $(\% 23,8)$. Bu sonuçlara göre dini değerler çalışma grubunda öncelikli bir değerdir sonucuna ulaşılabilir.

\subsubsection{Hoşgörü Değeri}


Tablo 15. Hoşgörü Değeri

\begin{tabular}{ccc}
\hline Öncelikler & Frekans & Yüzde $(\%)$ \\
\hline 1 & 8 & 4,7 \\
2 & 14 & 8,1 \\
3 & 15 & 8,7 \\
4 & 18 & 10,5 \\
5 & 30 & 17,4 \\
6 & 36 & 20,9 \\
7 & 39 & 22,7 \\
8 & 11 & 6,4 \\
Toplam & 170 & 100 \\
\hline
\end{tabular}

Hoşgörü Türk toplumunda önemli sayılan değerlerden biridir. Çalışma grubundan 8 kişi bu değeri birinci önceliğine yazmıştır. Hoşgörü değeri çalışma grubu tarafından 5.,6., ve 7., öncelik sırasında işaretlenmiştir (toplam \% 61). 11 kişi son değer olarak hoşgörüyü işaretlemiştir.

\subsubsection{Doğa ve Çevre Değeri}

Tablo 16. Doğa ve Çevre Değeri

\begin{tabular}{ccc}
\hline Öncelikler & Frekans & Yüzde (\%) \\
\hline 1 & 3 & 1,7 \\
2 & 1 & 6 \\
3 & 5 & 2,9 \\
4 & 9 & 5,2 \\
5 & 8 & 4,7 \\
6 & 18 & 10,5 \\
7 & 43 & 25,0 \\
8 & 84 & 48,8 \\
Toplam & 170 & 100 \\
\hline
\end{tabular}

Bir değer olarak Doğa ve Çevre çalışma gurubunda 3 kişi (\%1.7) tarafından birincil değer olarak görülmüştür. Bu hali ile birinci tercih olarak en az işaret alan değer olma özelliğini taşımaktadır. Çalışma grubunun \%73.8'si doğa ve çevre değerini 7 ve 8 . sırada değerlendirmiştir ( 127 kişi). Bu sonuçlar doğa ve çevrenin bir değer olarak gençlerin tam anlamlar dünyasın- da yer etmediğini göstermektedir. Bu yargıyı araştırmada sorulan evrensel ve yerel değerleriniz neler açı uçlu sorusuna verilen yanıtlar da desteklemektedir. Sadece bir kişi doğayı yerel değerleri arasında saymıştır. Bu durum üzerinde çok ciddi düşünülmesi gereken bir sonuçtur.

\subsubsection{Aile Değeri}

Tablo 17. Aile Değeri

\begin{tabular}{ccc}
\hline Öncelikler & Frekans & Yüzde (\%) \\
\hline 1 & 74 & 43,0 \\
2 & 44 & 25,6 \\
3 & 13 & 7,6 \\
4 & 7 & 4,1 \\
5 & 14 & 8,1 \\
6 & 8 & 4,7 \\
7 & 8 & 4,7 \\
8 & 3 & 1,7 \\
Toplam & 170 & 100 \\
\hline
\end{tabular}


Çalışma grubunun en yoğun şekilde birincil sıraya koyduğu değer aile değeridir. Aile değerini dini değerler takip etmektedir. Buna göre çalışma grubunun \%76.2'si aileyi öncelikli olarak ilk üç sıraya yazmıştır. Sadece 3 kişi (\%1.7) aileyi sonucu değeri olarak belirtmiştir.
Bu sonuç gösteriyor ki Aile, Türk toplumunun birinci değeridir. Bu yargıyı araştırmada sorulan evrensel ve yerel değerleriniz neler açık uçlu sorusuna verilen yanitlar da desteklemektedir.

\subsubsection{Barış ve Uzlaşma Değeri}

Tablo 18. Barış ve Uzlaşma Değeri

\begin{tabular}{ccc}
\hline Öncelikler & Frekans & Yüzde (\%) \\
\hline 1 & 9 & 5,2 \\
2 & 14 & 8,1 \\
3 & 32 & 18,6 \\
4 & 31 & 18,0 \\
5 & 34 & 19,8 \\
6 & 24 & 14,0 \\
7 & 25 & 14,5 \\
8 & 2 & 1,2 \\
Toplam & 170 & 100 \\
\hline
\end{tabular}

Barış ve Uzlaşma değeri günümüzde siyasal ve gündelik gündemde sıkça anılmakta ve tartışılmaktadır. Çalışma grubu barış ve uzlaşma değerini 3., 4., 5. sıralarda değerlendirmiştir (\%51.2). 9 kişi (\%5.2) birinci önceliğine, 2 kişi de son sıraya bu değeri yazmıştır (\%1.2). Bu verilere göre Barış ve Uzlaşma çalışma grubunun önemsediği bir değerdir. Bu yargıyı araştırmada sorulan evrensel ve yerel değerleriniz neler açık uçlu sorusuna verilen yanıtlar da desteklemektedir. Çalışma grubu bu değeri birinci evrensel değer olarak görmüştür.

\subsection{7. Özgürlük Değeri}

Tablo 19. Özgürlük Değeri

\begin{tabular}{ccc}
\hline Öncelikler & Frekans & Yüzde (\%) \\
\hline 1 & 22 & 12,8 \\
2 & 33 & 19,2 \\
3 & 38 & 22,1 \\
4 & 30 & 17,4 \\
5 & 20 & 11,6 \\
6 & 12 & 7,0 \\
7 & 6 & 3,5 \\
8 & 10 & 5,8 \\
Toplam & 170 & 100 \\
\hline
\end{tabular}

Evrensel değerlerden olan özgürlük değeri, üniversite öğrencileri ve üniversite mezunu gençlerden oluşan çalışma grubu tarafından önemsenen bir değerdir. Çalışma grubunun \%54.1'i özgürlük değerini ilk üç sırada değerlendirmiştir. Sadece 10 kişi (\%5.8) özgürlüğü son sıraya yerleştirmiştir.

\subsection{8. İnsan Hakları Değeri}

Tablo 20. İnsan Hakları Değeri

\begin{tabular}{ccc}
\hline Öncelikler & Frekans & Yüzde (\%) \\
\hline 1 & 17 & 9,9 \\
2 & 30 & 17,4 \\
3 & 24 & 14,0 \\
\hline
\end{tabular}




\begin{tabular}{lcc}
\hline 4 & 36 & 20,9 \\
5 & 25 & 14,5 \\
6 & 22 & 12,8 \\
7 & 12 & 7,0 \\
8 & 5 & 2,9 \\
Toplam & 170 & 100 \\
\hline
\end{tabular}

Çalışma grubunun \%41.3'ü evrensel bir başka değer olan insan haklarını ilk üç önceliğinde görmüştür. 4. ve 5. Sıraya bu değeri yerleştirenlerin oranı ise \%35.4'tür. İnsan haklarını son sırada gören kişi sayısı $5^{\prime}$ tir (\% 2.9). Evrensel değerler olarak betimlenen barış, özgürlük ve insan hakları çalışma grubu tarafından önemsenmektedir sonucuna bu veriler ışığında ulaşılabilir.

Sonuç olarak çalışma grubunun birinci sıraya koyduğu değerler sıralaması şöyledir;

1. Aile

2. Din

3. Özgürlük

4. İnsan hakları

5. Barış ve Uzlaşı

6. Hoşgörü

7. Demokrasi

8. Doğa ve Çevre

Çalışma grubunun sonuncu sıraya koyduğu değerler sıralaması şöyledir;
1. Doğa

2. Din

3. Demokrasi

4. Hoşgörü

5. Özgürlük

6. İnsan Hakları

7. Aile

8. Barış

\subsection{Evrensel ve Yerel Olarak Anlamlandird1- ğınız Değerleriniz Nelerdir?}

"Çalışma grubuna evrensel olarak ve yerel olarak anlamlandırdığınız değerleriniz nelerdir?" Sorusu açık uçlu olarak sorulmuş daha sonra bu yanitlar listelenerek yüzde ve frekansları çıkarılarak nicelleştirilmiştir.

\subsubsection{Evrensel Değerler}

Evrensel değer olarak çalışma grubu 32 değer yazmıştır. Buna göre aşağıdaki sonuçlara erişilmiştir;

Tablo 21. Çalışma Grubu Tarafından Oluşturulan Evrensel Değerler

\begin{tabular}{lcc}
\hline \multicolumn{1}{c}{ Değer } & Frekans & Yüzde (\%) \\
\hline Barış & 34 & 19,8 \\
İnsan Hakları & 29 & 16,9 \\
Özgürlük & 24 & 14,0 \\
Aile & 9 & 5,2 \\
Hoşgörü & 9 & 5,2 \\
Din & 7 & 4,1 \\
Demokrasi & 5 & 2,9 \\
Saygı & 5 & 2,9 \\
Ahlak & 4 & 2,3 \\
Barış Ve Din & 3 & 1,7 \\
Adalet & 2 & 1,2 \\
Barış Ve İnsan Hakları & 2 & 1,2 \\
Barış Ve Özgürlük & 2 & 1,2 \\
Dürüstlük & 2 & 1,2 \\
Eşitlik & 2 & 1,2 \\
\hline
\end{tabular}




\begin{tabular}{|c|c|c|}
\hline Sevgi Ve Dostluk & 2 & 1,2 \\
\hline Aile Ve Akrabalar & 1 & 6 \\
\hline Aile Ve Din & 1 & 6 \\
\hline Barış Ve Hoşgörü & 1 & 6 \\
\hline Barış Ve Sevgi & 1 & 6 \\
\hline Dil & 1 & 6 \\
\hline Dünya Barışı & 1 & 6 \\
\hline Evrensel Ahlak & 1 & 6 \\
\hline Hoşgörü ve Adalet & 1 & 6 \\
\hline Hoşgörü ve Sevgi & 1 & 6 \\
\hline Kokoreç & 1 & 6 \\
\hline Misafirperverlik & 1 & 6 \\
\hline Müzik ve Din & 1 & 6 \\
\hline Para & 1 & 6 \\
\hline Sevgi & 1 & 6 \\
\hline Vatan & 1 & 6 \\
\hline Yaşam hakkı & 1 & 6 \\
\hline Boş & 13 & 7.6 \\
\hline Toplam & 170 & 100,0 \\
\hline $\begin{array}{l}\text { Tabloda da görülebileceği gibi çalışma grubu } \\
\text { evrensel değerlerler olarak öncelikle barış, } \\
\text { insan hakları ve özgürlük değerlerini ilk yaz- } \\
\text { mıştır. Evrensel bir değer olarak barış } 34 \text { kişi ile } \\
\text { \%19.8'lik bir orana sahiptir. İnsan hakları } 29 \\
\text { kişi ile \%16.9, Özgürlük, \%14'lük bir orandadır. } \\
\text { Aile, hoşgörü ve din gibi değerlerde sırasıyla } \\
\text { bunları takip etmiştir. Bu değerleri çalışma } \\
\text { grubu aynı zamanda yerel değerlerin ilk üç } \\
\text { sırasına yerleştirmişlerdir. Adalet, dürüstlük, } \\
\text { Tablo 22. Çalışma Grubu Tar }\end{array}$ & \multicolumn{2}{|c|}{$\begin{array}{l}\text { eşitlik, sevgi gibi değerleri yazanlar ise az sayı- } \\
\text { dadır. } \\
\text { 3.3.2 Yerel Değerler } \\
\text { Yerel olarak anlamlandırdığınız değerleriniz } \\
\text { nelerdir? Sorusu açık uçlu olarak sorulmuş } \\
\text { daha sonra bu yanıtlar listelenerek yüzde ve } \\
\text { frekansları çıkarılarak nicelleştirilmiştir. Yerel } \\
\text { değer olarak çalışma grubu } 44 \text { değer yazmıştır } \\
\text { Buna göre aşağıdaki sonuçlara erişilmiştir; } \\
\text { n Oluşturulan Yerel Değerler }\end{array}$} \\
\hline Değer & Frekans & Yüzde (\%) \\
\hline Aile & 44 & 25,6 \\
\hline Din & 12 & 7,0 \\
\hline Hoşgörü & 12 & 7,0 \\
\hline Gelenek & 10 & 5,8 \\
\hline Aile Ve Din & 8 & 4.6 \\
\hline Kültür & 7 & 4,1 \\
\hline Sayg1 & 6 & 3,5 \\
\hline Ahlak & 4 & 2,3 \\
\hline Gelenek Ve Görenek & 4 & 2,3 \\
\hline Özgürlük & 4 & 2,3 \\
\hline Bağımsızlık & 2 & 1,2 \\
\hline Aileye Sayg1 & 2 & 1,2 \\
\hline Barış & 2 & 1,2 \\
\hline Demokrasi & 2 & 1,2 \\
\hline Aile Ve Gelenekler & 2 & 1,2 \\
\hline Aile Ve Kültür & 1 & 6 \\
\hline Aile Ve Sayg1 & 1 & 6 \\
\hline
\end{tabular}




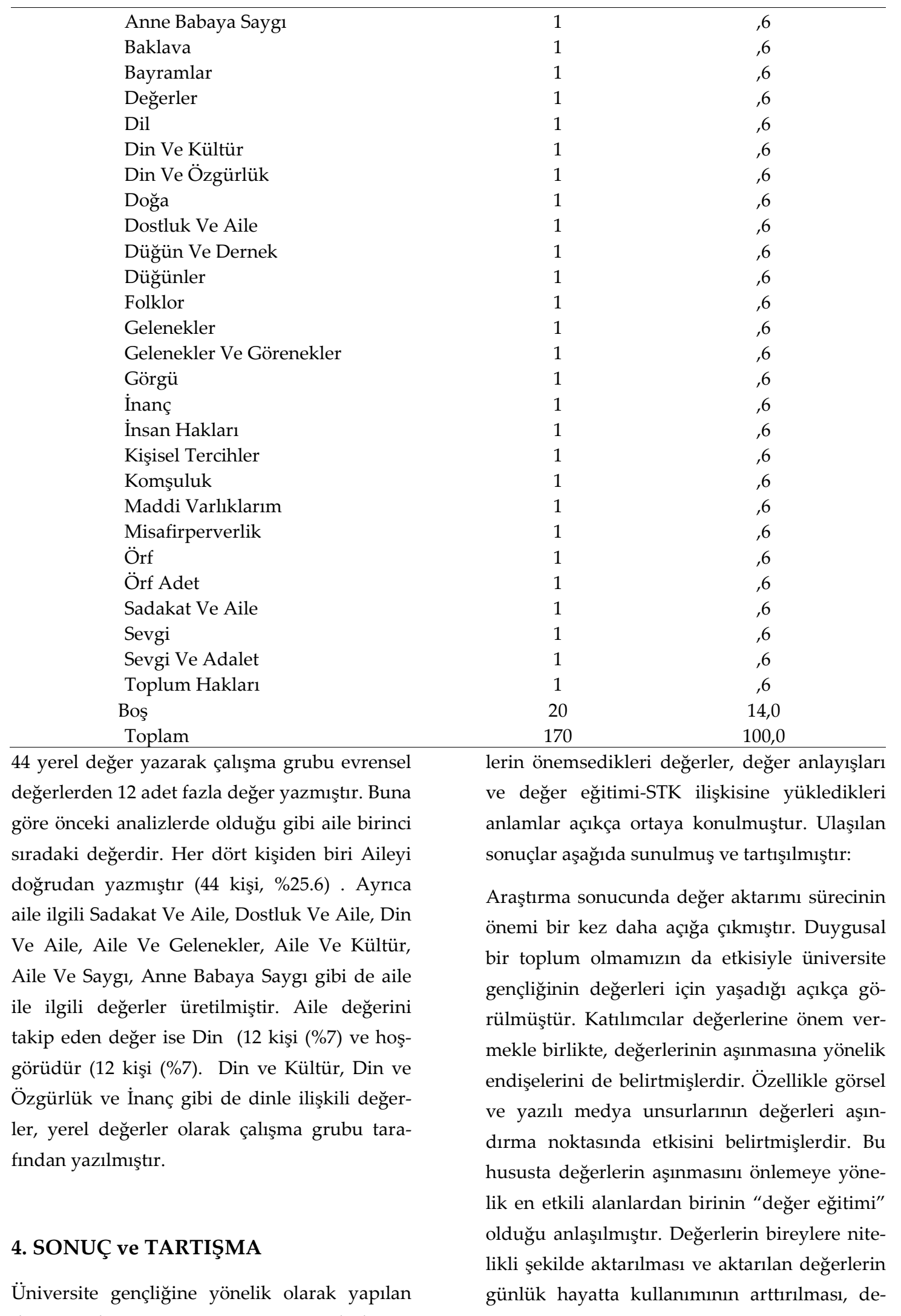


ğerlerin aşınmasını önleyici bir tavır olacaktır. Araştırma sonucunda kişilerin ailelerinden farklı değerleri de benimsediği dikkat çekmektedir. $\mathrm{Bu}$ farklı tercihlerin bireysel özgürlük anlamında önemli bir gelişme olduğuna sonucuna ulaşılabilir. Katılımcıların aile değerini yoğun bir şekilde vurguladıkları görülmüştür. Araştırmada katılımcıların Aile, Din ve Hoşgörüyü yerel değerler olarak gördükleri sonucuna ulaşılmıştır. Evrensel değerler bağlamında ise Barış, İnsan Hakları ve Özgürlük değerlerinin ön plana çıktı̆̆1 görülmüştür. Bu bağlamda, Memiş ve Gedik (2010) yaptıkları çalışmalarında, barış, insan hakları ve özgürlük gibi özellikleri de içinde barındıran evrensellik değerinin sınıf öğretmenlerinin en çok önem verdiği değer olduğu sonucuna ulaşmıştır. Bu konuda Tatlıdil ve Günder (2013), değerler sisteminin hem yerel hem küresel nitelikleri bir arada taşıması gerektiğini belirtmiş, yerelliğin yanında insan haklarına ve farklılıklara saygı, hoşgörü, işbirliği, yardımlaşma gibi evrensel nitelikteki değerlerin korunması ve geliştirilmesi gerekliliğini belirtmişlerdir. Balay (2004) da çalışmasında küreselleşme ile birlikte yerel ve evrensel değerler ayrımının aksine insanlığın ortak değerlerinin oluşmaya başladığını belirtmiştir.

Katılımcilar öğretmenin değer aktarımında önemli bir yere sahip olduğunu belirtmişlerdir (Oğuz, 2012). Buradan değer aktarımının sadece ailede ya da çevrede değil aynı zamanda planlı süreçlerin işe koşulduğu okullarda da öğretmenler tarafından da etkili biçimde yapılabileceği sonucuna ulaşılabilir. Bu bağlamda, katılımcılar okullara değer eğitimi adı altında bir ders konulmasına da olumlu bakmaktadırlar (Fidan, 2009). Bu noktada da önemli bir sorun Tatlıdil ve Günder (2013) tarafından dile getirilmiştir. Araştırmacılar, öğretmenlerin küreselleşen dünyada ortaya çıkan yeni değerlere uyum konusunda eksikliklerinin bulunduğunu belirtmişlerdir. Bu durumu destekleyen diğer bir araştırma da Kurtulmuş ve diğ. (2014) tarafından yapılmış, öğretmenlerin değer eğitimi konusunda yeterli bilgilerinin olmaması, okulda yapılması planlanan değer eğitiminin etkili olmayacağını düşünmeleri ve değer eğitimini önemsiz görmeleri nedenleriyle etkili değer eğitimi için sakıncaları ortaya koymuşlardır. Bu sorunun doğrudan değer eğitimi sürecini etkileyeceği düşünülmektedir. Fakat bu noktada yaşanan diğer bir sorun da değer eğitiminde okulun ön plana çıkarılıp, aile ve çevrenin geri plana itilmesidir. Yazıcı (2006) da değer eğitimine ilişkin yaptığ çalışmanın sonucunda değer eğitiminin okul ve ailede tutarlı şekilde sürdürülmesi gerektiğini belirtmiştir.

Araştırma sonucunda dikkat çeken bir nokta da sivil toplum kuruluşları hususunda görülmüştür. Katılımcılar, sivil toplum kuruluşlarının değer eğitiminde önemli bir yerinin olduğunu, sivil toplumun kuruluşlarının kendisinin bir değer olduğunu, sivil toplum ve MEB'in işbirliği yapması gerektiğini ve sivil toplum kuruluşlarının yeni değerler üretebileceğini düşündüklerini vurgulamışlardır. Bu bulgulara göre kişilerin zihinlerindeki sivil toplum kuruluşu hakkındaki şemaların değiştiği söylenebilir. Bu değişim sivil toplum kuruluşlarının tamamen devlet dışında var olma anlayışını da değiştirmede rol oynayabilir. Eraslan ve diğ. (2015) yaptıkları çalışmada, sivil toplum kuruluşlarının, içerik ve materyal oluşturma, öğretmen eğitimi, ekonomik katkı sağlama, kamuoyu oluşturma gibi birçok alanda değer eğitimi sürecine işbirliği ekseninde katkı sağlayabileceğini vurgulamışlardır. Sivil toplum kuruluşlarının başta eğitim olmak üzere çeşitli alanlarda devlet kurumlarıyla işbirliği yaparak katkı sağlayabileceği öngörülmektedir. Bu görüşü Akpınar ve Özdaş'ın (2013) öğretmenlerle gerçekleştirdikleri çalışmanın sonuçları da desteklemektedir. Buna ek olarak Tatlıdil ve Günder (2013) de çalışmalarının sonucunda eğitimin program ve uygulamalarında çevreyle 
işbirliği yapmaları gerekliliğini belirtmişlerdir Sivil toplum kuruluşları ve devlet arasında kurulacak iyi bir diyalog var olan sorunların çözümünü de kolaylaştıracaktır.

\section{5. ÖNERİLER}

1. Değer kavramı, öğretimin her kademesinde ders bazında konu konu değil müstakil bir ders olarak verilmelidir. MEB tarafından ilköğretim ve ortaöğretim öğretim programlarına "Değerler Eğitimi" adlı ders konulmalıdir.

2. Değer öğretimi sürecinin sadece okullardaki bilgi aktarımı ve uygulamalardan olmadiğı anlaşılmalı ve sürece çevresel aktörlerin etkin katılımı sağlanmalıdır.

3. Sivil toplum kuruluşları bağlamında, okulSTK işbirliği güçlendirilmeli, öğretim programları, ders kitapları ve eğitim materyalleri tasarımında farklı ideolojik yapılardaki STK'ların fikirleri alınmalıdır.
4. Okulların ihtiyaçları ekseninde STK'ların ekonomik kapasite yaratma ve kamuoyu oluşturma gücünden yararlanılmalıdır.

5. Yerel-kültürel değerlerin korunmasının yanında insan onurunu yücelten evrensel değerlere ilişkin vurgular öğretim programlarında daha fazla yer almalıdır.

6. Temel değerler ve değer eğitimi konusunda ailelere de yaygın eğitim uygulanmalı, ebeveynlerin öğrencilere değer eğitimi sürecinde nasıl yardım edebileceği açıkça ifade edilmelidir.

7. Öğretmenlerin değer eğitimine ilişkin bakış açıları değiştirilmeli, gerekli donanıma sahip olmaları ve değer eğitimi sürecinin toplumu şekillendirici etkisinin farkına varmaları sağlanmalıdır.

\section{Kaynakça}

Aktaş, M. C. (2014). Nitel Veri Toplama Araçları. M. Metin (Ed.). Eğitimde Bilimsel Araştırma Yöntemleri. Ankara: Pegem Akademi.

Akpınar, B ve Özdaş, F. (2013). İlköğretimde Değer Eğitimine İlişkin Öğretmen Görüşleri: Nitel Bir Analiz, Frat Üniversitesi Sosyal Bilimler Dergisi, 23 (2): 105-113.

Balay, R. (2004). Küreselleşme, Bilgi Toplumu ve Eğitim. Ankara Üniversitesi Eğitim Fakültesi Dergisi, 37 (2): 61-82.

Bolay, S. H. (2007). Değerlerimiz ve Günlük Hayat, Değerler Eğitimi Dergisi, 1 (1): S. 12-19.

Büyüköztürk, Ş., Çakmak, E.K., Akgün, Ö.E., Karadeniz, Ş. ve Demirel, F. (2013). Bilimsel Araştırma Yöntemleri, Ankara: Pegem Akademi.

Dilmaç, B, Deniz, M ve Deniz, M.E. (2009). Üniversite Öğrencilerinin Öz-Anlayışları İle Değer Tercihlerinin İncelenmesi. Değerler Ĕ̆itimi Dergisi, 7 (18): 9-24.

Doğan, İ. (2011). Ĕ̆itim Sosyolojisi, Ankara: Nobel Yayınları.

Eraslan, L. (2013). Değerler Eğitiminde Sivil Toplum Katılımı ve Sivil Toplum Kuruluşlarının Rolü (Üniversite Gençliği Dĕ̆er Analizi). Uluslararası Antalya Değerler Eğitimi Sempozyumu, Antalya. 
Eraslan, L, Erdoğan, E ve Hayran, Y. (2015). Can Civilians Contribute to Education? The Impact of Non Govermental Organizations in Value Education. International Journal of Academic Research in Education and Review, 3 (4): 87-99.

Fidan, K., N. (2009). Öğretmen Adaylarının Değer Öğretimine İlişkin Görüşleri. Kuramsal Eğitimbilim, 2 (2): 1-18.

Gray, R. (2002) The Social Accounting Project And Accounting Organizations And Society: Privileging Engagement, İmaginings, New Accountings And Pragmatism Over Critique? Accounting, Organizations and Society, 29 (7):687-708.

Hildy, T. (2004). The İmportance Of Nongovernmental Organizations (Ngos) İn Global Governance And Value Creation: An İnternational Business Research Agenda, Journal of International Business Studies, 35: 463-483.

Kurtulmuş, M, Tösten, R ve Gündaş, A. (2014). İlköğretim 1.Kademe Öğretmenlerinin Değerler Eğitimi Sürecinde Karşılaştıkları Sorunlar. Değerler Eğitimi Dergisi, 12 (27): 281-305.

Macionis, J. J. (2012). Sociology (Sosyoloji), Ankara: Nobel Yayıncılık.

MEB. (2005). İlköğretim Sosyal Bilgiler Dersi (4-5. Sinıflar) Öğretim Programı ve Kılavuzu. Ankara: Devlet Kitapları Müdürlüğü.

Memiş, A ve Gedik, E, G. (2010). Sınıf Öğretmenlerinin Değer Yönelimleri. Değerler Eğitimi Dergisi, 8 (20): 123-145.

Neachu, M. (2013). Promoting Education for Values In the Scholar Curriculum. Journal of Plus Education, 9 (1): 106-112.

Oğuz, E. (2012). Öğretmen Adaylarının Değerler ve Değerler Eğitimine İlişkin Görüşleri, Kuram ve Uygulamada Ĕ̆itim Bilimleri, 12 (2): 1309-1325.

Tatlıdil, E ve Günder, E, E. (2013). Küreselleşen Değerlerin Eğitim Kurumları Üzerine Etkisi. Değerler Ĕ̆itimi Dergisi, 11 (26): 259-277.

Yazıcı, K. (2006). Değerler Eğitimi'ne Genel Bir Bakış, TüBAR, 19: 499-522.

Yel, S. ve Aladağ, S. (2012). Sosyal Bilgilerde Değerlerin Öğretimi. M. Safran (Ed.), Sosyal Bilgiler Öğretimi (119-150) Ankara: Pegem Akademi.

Yıldırım, A ve Şimşek, H. (2013). Sosyal Bilimlerde Nitel Araştırma Yöntemleri, Ankara: Seçkin Yayıncılık.

Yılmaz, E. (2009). Öğretmenlerin Değer Tercihlerinin Bazı Değişkenler Açısından İncelenmesi. Değerler Ĕ̆itimi Dergisi: 7 (17): 109-128.

\section{İnternet Kaynakları}

Türk Dil Kurumu (TDK), www.tdk.gov.tr Erişim: 25.12.2014 


\section{Extended Summary}

\section{Purpose}

In the recent years, value education has become one of the important study fields. It is foreseen that it will maintain its importance for providing healty society order in the coming years. University students play an important role in the future of countries. For this reason, identification of university youth's values will bring benefit to maintaining to social order. This research also aims to specify university students' perpectives devoted to both value concepts and non govermental organizations - value relations within the context of values education.

\section{Method}

The research was designed with both quantitative and qualitative method. The study is descriptive in terms of quantitative method. In terms of qualitative method, universal and local value perceptions were asked to participants. In the analysis of quantative datas, SPSS 15. 0 package software was used, percentage and frequency values were indicated. Furthermore, in the analysis of qualitative datas, content analysis method was used. Research's study group comprises of 170 university students and graduate students in the age of between $18-28$. Study group of university students involves in psychological counseling and guidance, Turkish education, primary school teacher training, computer and instructional technologies, graduate students group comprises of management, economy, econometrics, public administration, literature, history, geography, music, religious culture and mathematics.

\section{Findings}

According to findings of this research, university youth has not held similar views with their families about value preferences. In addition to this, university youth has especially emphasized family value. Furthermore, while university youth indicates family, religion and tolerance as local value, they remarks peace, freedom and human rights as universal value. Participants think that teachers play an important role in process of value transfer. University youth has also emphasized that non govermental organizations can contribute to value education process.

\section{Results and Suggestions}

In the consequence of this research, non govermental organizations' importance in the process of value formation and taking responsibility in education were indicated by university youth. It is understood that university youth lives for values in Turkey. As a result of this research, it is comprehended that apart from family and environment, teacher also plays an important role in value transfer process. University youth cares world peace, human rights and personal freedoms.

According to these results, it is suggested that Ministry of National Education should design a value education curriculum for primary education and secondary education. Family participation to value teaching process should be increased. In the context of basic values, families should be educated. Participation of non govermental organizations to formal education process should be supported. In terms of molding public opinion and creating economic capacity should be benefited from non-govermental organizations. Awareness of teacher about the value education also should be developed. 